$\xi=$ 离

\title{
A concise review on hypophosphatasia with case report
}

\author{
Jaspinder Kaur*, Soheila Nourabadi ${ }^{1}$, Luis Chavez, Issac Sachmechi \\ Department of Internal Medicine, Icahn School of Medicine at Mount Sinai, Queens Hospital Center, Jamaica, NY, U.S.A 11432 \\ *Corresponding author E-mail:mailtojaspinder@yahoo.in
}

\begin{abstract}
Hypophosphatasia (HPP) is an inherited dento-osseous metabolic disease characterized by inactivating mutations in the gene encoding the tissue-nonspecific isoenzyme of alkaline phosphatase (TNSALP) which lead to a deficiency in TNSALP enzymatic activity. Low TNSALP activity results in increased levels of 3 known phosphocompound substrates: inorganic pyrophosphate (PPi), pyridoxal 5'phosphate (PLP; the major circulating form of vitamin B6), and phosphoethanolamine (PEA). We discussed a systematic review with novel approach and a case report in which patient had multiple jaw reconstructive surgeries and early tooth loss in his childhood age but remained undiagnosed till his 60s. It should raise awareness among health care providers regarding low TNSALP and performing thorough etiological investigations which can ensure optimal clinical care and decision making for their patients by preventing complications like chondrocalcinosis, arthritis, early tooth loss, pseudo/complete fractures and pseudogout among the patients diagnosed with HPP even later in their life.
\end{abstract}

Keywords:Hypophosphatasia; Inorganic Pyrophosphate; Pyridoxal 5'-Phosphate; Phosphoethanolamine; Tissue-Nonspecific Isoenzyme of Alkaline PhosPhatase.

\section{Introduction}

Dr. Rathbun in 1946 introduced an inherited dento-osseous metabolic disease characterized by inactivating mutations in the gene encoding the tissue-nonspecific isoenzyme of alkaline phosphatase (TNSALP) which lead to a deficiency in TNSALP enzymatic activity - the primary biochemical defect in Hypophosphatasia (HPP) (Mumm et al 2001). HPP is classified into five major categories depending upon the age at diagnosis: perinatal, infantile, childhood, adult and odonto forms (Table 1). Moreover, the perinatal form was further divided into two types, lethal and benign. The symptoms are highly variable in their clinical expression, which ranges from stillbirth without mineralized bone to early loss of tooth without bone symptoms. However, these clinical subtypes often overlap, for instance infantile and childhood hypophosphatasia share some clinical symptoms; and patients with adult hypophosphatasia often had some clinical symptoms already in childhood. The clinical severity is correlated inversely with age of onset of the skeletal disease and with the circulating age-appropriate levels of TNSALP activity; and directly with plasma pyridoxal 5'phosphate (PLP) concentrations (Whyte et al 2001).

\section{Incidence/prevalence}

Severe HPP has an estimated incidence of 1:100,000 in Toronto, Canada (Fraser 1957) and an estimated prevalence of 1:300,000 in Europe/France (Mornet et al 2011). HPP is especially highly prevalent in the Mennonite population in Manitoba, Canada, owing to a particular founder mutation estimated to have a carrier frequency of 1:25 resulting in a predicted frequency of homozygous affected newborns of 1:2500 manifesting severe disease (Leung et al 2013). About one out of every 200 individuals in the United States may be a "carrier" for HPP. HPP primarily occurs in Caucasians but has been observed in Japanese, Hispanic, and Native American populations; though very rare among the African-American population (Mornet 2016).

\section{Classification}

Table 1: Classification of Hypophosphatasia

\begin{tabular}{|c|c|c|c|c|c|}
\hline Features & Perinatal Onset & Infantile Onset & Childhood Onset & Adult Onset & Odontohypophosphatasia \\
\hline Age at onset & $\begin{array}{l}\text { In utero (lethal) } \\
\text { At birth (benign) }\end{array}$ & & $\begin{array}{l}6 \text { months to } 18 \text { years } \\
\text { of age }\end{array}$ & $\geq 18$ years of age & $\begin{array}{l}\text { Variable age presenta- } \\
\text { tion }\end{array}$ \\
\hline $\begin{array}{l}\text { Clinical } \\
\text { signs/symptoms }\end{array}$ & $\begin{array}{l}\text { Apnea } \\
\text { Fractures } \\
\text { Hypomineralized bones } \\
\text { Long Bone deformity } \\
\text { Osteochondral spurs } \\
\text { Poorly ossified epiphy- } \\
\text { ses } \\
\text { Radiolucencies into } \\
\text { metaphyses }\end{array}$ & $\begin{array}{l}\text { Craniosynostosis } \\
\text { Failure to thrive } \\
\text { Fractures } \\
\text { Hypercalcemia/ } \\
\text { Hypercalciuria } \\
\text { Hypomineralization } \\
\text { Hypotonia } \\
\text { Nephrocalcinosis } \\
\text { Poor feeding }\end{array}$ & $\begin{array}{l}\text { Chronic muscle/bone } \\
\text { pain } \\
\text { Hypomineralization } \\
\text { Low bone mineral } \\
\text { density } \\
\text { Missed/Delayed motor } \\
\text { milestones } \\
\text { Muscle weakness } \\
\text { Poorly healing or re- } \\
\end{array}$ & $\begin{array}{l}\text { Abnormal dentition } \\
\text { Adult tooth loss } \\
\text { Chondrocalcinosis } \\
\text { Chronic muscle/bone pain } \\
\text { Hypomineralization } \\
\text { Osteoarthropathy } \\
\text { Osteomalacia } \\
\text { Pseudofractures/Fractures } \\
\text { Pseudogout }\end{array}$ & $\begin{array}{l}\text { Loss of alveolar bone } \\
\text { Exfoliation (incisors) } \\
\text { Reduced thickness of the } \\
\text { dentin } \\
\text { Enlarged pulp chambers } \\
\text { of teeth } \\
\text { Dental caries }\end{array}$ \\
\hline
\end{tabular}

Copyright $\odot$ 2016JaspinderKaur et al. This is an open access article distributed under the Creative Commons Attribution License, which permits unrestricted use, distribution, and reproduction in any medium, provided the original work is properly cited. 


\begin{tabular}{|c|c|c|c|c|c|}
\hline & Severe chest deformity & Poor weight gain & current fractures & Myopathy & \\
\hline & Stillbirth & Premature deciduous & Premature tooth loss & Arthropathy & \\
\hline & Vitamin B6 responsive & tooth loss & Rachitic deformity & Calcific arthritis, spine & \\
\hline & seizures & Pulmonary insuffi- & Short stature & ligaments & \\
\hline & Caput membranaceum & ciency & Skeletal deformity & Calcific Periarthritis & \\
\hline & Shortened limbs & Rickets & Brachycephalic skull & Poorly healing or recur- & \\
\hline & Rachitic deformities & $\begin{array}{l}\text { Vitamin B6 respon- } \\
\text { sive seizures }\end{array}$ & $\begin{array}{l}\text { Dolichocephalic skull } \\
\text { Enlarged joints } \\
\text { Delayed walking } \\
\text { Waddling Gait }\end{array}$ & rent fractures & \\
\hline $\begin{array}{l}\text { Mode of inher- } \\
\text { itance }\end{array}$ & $\mathrm{AR}$ or $\mathrm{AD}$ & AR & $\begin{array}{l}\mathrm{AR} \text { (frequent)/AD } \\
\text { (rare) }\end{array}$ & $\mathrm{AR}$ or $\mathrm{AD}$ & $\mathrm{AR}$ or $\mathrm{AD}$ \\
\hline $\begin{array}{l}\text { Prognosis and } \\
\text { Level of severi- } \\
\text { ty }\end{array}$ & $\begin{array}{l}\text { Most severe form; } \\
\text { almost always lethal. } \\
25 \% \text { chances of reoc- } \\
\text { currence in future } \\
\text { pregnancies. }\end{array}$ & $\begin{array}{l}\text { Severe form; Ap- } \\
\text { proximately } 50 \% \text { of } \\
\text { affected infants die. } \\
\text { Others spontaneously } \\
\text { recover and graded as } \\
\text { benign perinatal } \\
\text { HPP. }\end{array}$ & $\begin{array}{l}\text { Moderate form; } \\
\text { seems to improve } \\
\text { spontaneously when } \\
\text { growth plates fuse in } \\
\text { young adult life, but } \\
\text { recurrence of symp- } \\
\text { toms and complica- } \\
\text { tions later is possible. }\end{array}$ & $\begin{array}{l}\text { Moderate form; believed to } \\
\text { have normal lifespan. } \\
\text { Roughly half of them re- } \\
\text { quire assistive devices (eg, } \\
\text { wheelchair, walking de- } \\
\text { vice); and many need to } \\
\text { modify their home environ- } \\
\text { ment. }\end{array}$ & $\begin{array}{l}\text { Least lethal form; be- } \\
\text { lieved to have normal } \\
\text { lifespan. }\end{array}$ \\
\hline $\begin{array}{l}\text { Differential } \\
\text { Diagnosis }\end{array}$ & $\begin{array}{l}\text { Osteogenesisimperfecta } \\
\text { Achondrogenesis }\end{array}$ & Rickets & $\begin{array}{l}\text { Chronic Recurrent } \\
\text { Multifocal Osteomy- } \\
\text { elitis } \\
\text { Rickets } \\
\text { Malignancy }\end{array}$ & Osteomalacia & \\
\hline
\end{tabular}

\section{Etiopathogenesis}

In the healthy human skeleton, TNSALP functions as an ectoenzyme anchored to the outer surface of specialized buds of osteoblast and chondrocyte plasma membranes called matrix vesicles, the structures within which hydroxyapatite crystals formed first (Anderson 1997). Here, inorganic pyrophosphate (PPi) pumped extracellularly by the membrane channel protein ANK or produced extracellularly by nucleoside triphosphate pyrophosphatase (NTP-PPi-ase or PC-1) which is then hydrolyzed by TNSALP (Ho et al 2000). This reaction removes the potent inhibitor of hydroxyapatite crystal nucleation and growth called $\mathrm{PPi}$; and produces inorganic monophosphate ions $(\mathrm{Pi})$ that perhaps promotes bone mineralization (Anderson et al 2004) [Figure 1].

In HPP, though hydroxyapatite crystals nucleate within matrix vesicles (primary mineralization), but excess extracellular PPi hinders hydroxyapatite crystal growth and proliferation (secondary mineralization) which leads to defective mineralizaion of bone and cementum resulting in rickets and osteomalacia (Anderson 1997, Anderson et al 2004). It shows that normal primary mineralization of bone structural units occurs but defective maturation component results in an impaired secondary mineralization among patient with HPP [Figure 2].

The human ALP isoenzyme family is encoded by 4 separate genes. Three of the genes each encode a single ALP isoenzyme specific to the intestines, placenta, and germ cells, respectively. The fourth gene, TNSALP, encodes an ALP isoenzyme that is expressed ubiquitously; the highest levels of expression occur in the liver, bone, and kidney. Differences in catalytic activity of liver, kidney, and bone TNSALP result from varying posttranslational glycolsylation modifications (Buchet et al 2013). Low TNSALP activity results in increased levels of 3 known phosphocompound substrates: inorganic pyrophosphate (PPi), pyridoxal 5'-phosphate (PLP; the major circulating form of vitamin B6), and phosphoethanolamine (PEA) [Figure 3].
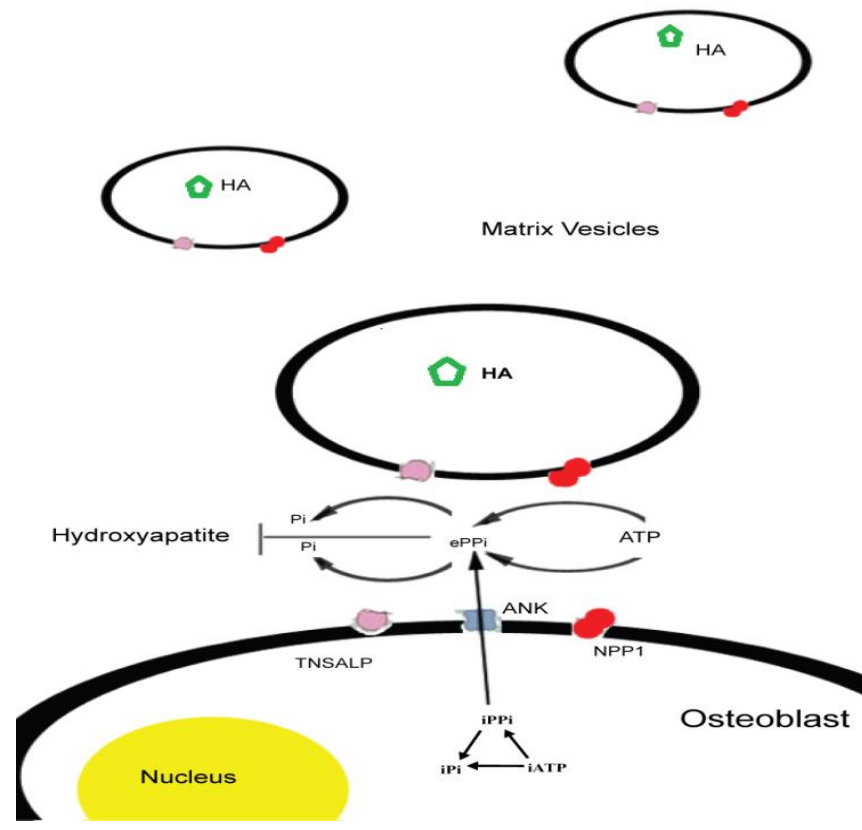

Fig. 1: Diagrammatic Presentation of TNSALP Hydrolyzing PPi to Pi and Promoting Hydroxyapatite Crystal Nucleation and Growth and Hence Bone Mineralization.

(TNSALP: Tissue-nonspecific isoenzyme of alkaline phosphatase; HA: Hydroxyapatite; ANK: Ankyrin; PPi: Inorganic pyrophosphate; Pi: Inorganic phosphate; NPP-1: nucleoside triphosphate pyrophosphatase-1; ATP: Adenosine triphosphate) 


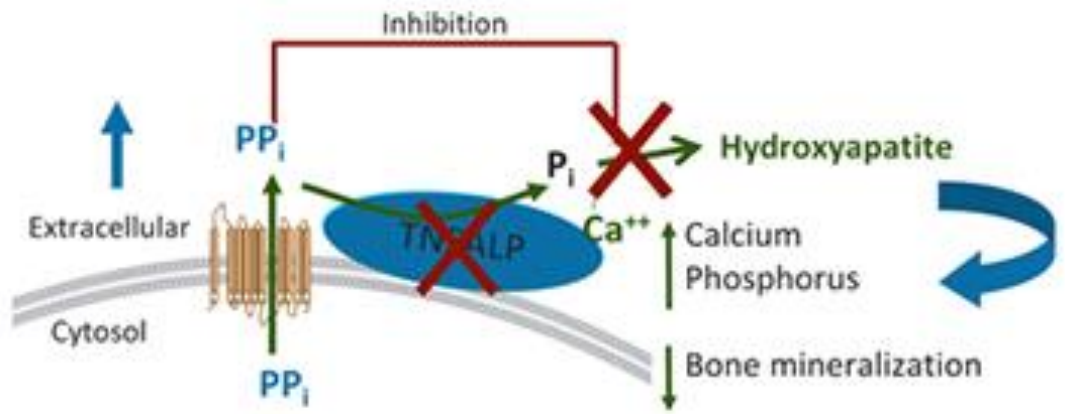

Fig. 2: Low TNSALP Leads to Extracellular Accumulation of PPi and Defective Mineralizaion of Bone and Cementum Resulting in Rickets and Osteomalacia

(TNSALP: Tissue-nonspecific isoenzyme of alkaline phosphatase; PPi: Inorganic pyrophosphate; Pi: Inorganic phosphate; $\mathrm{Ca}^{+2}$ : Calcium)

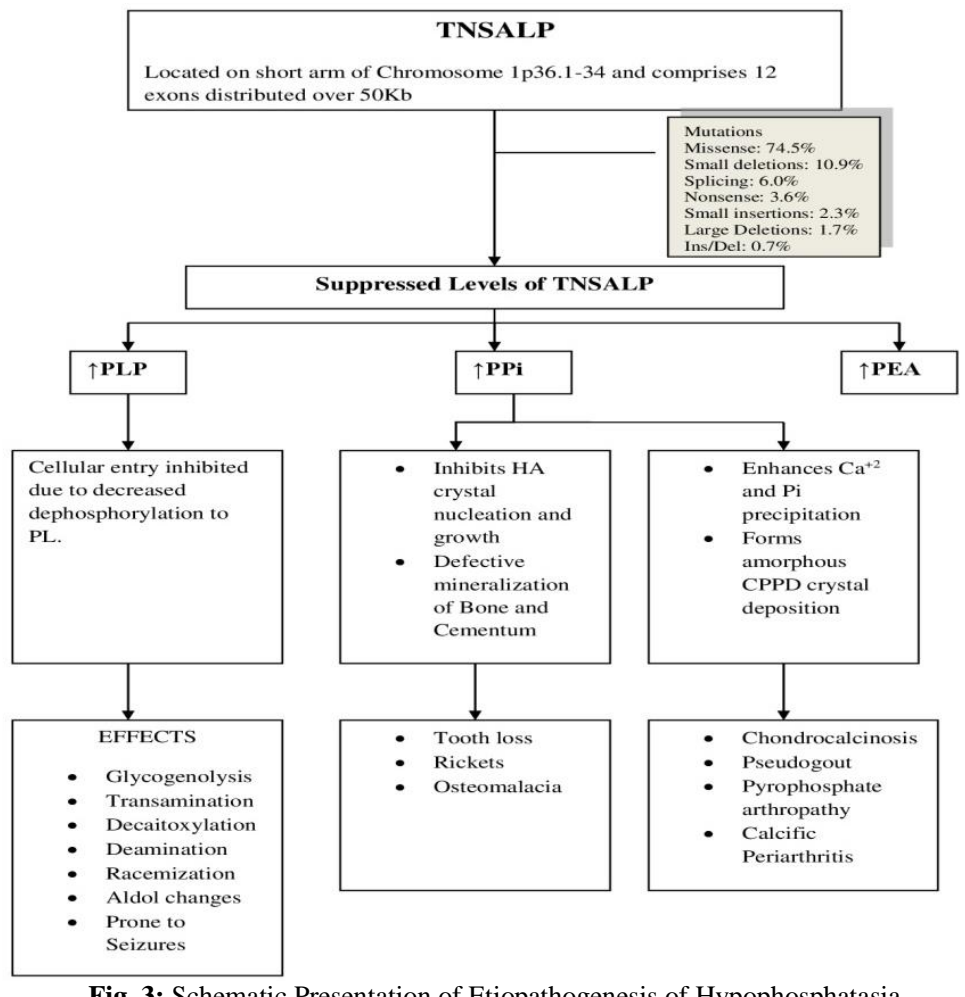

Fig. 3: Schematic Presentation of Etiopathogenesis of Hypophosphatasia

(TNSALP: Tissue-nonspecific isoenzyme of alkaline phosphatase, PLP: pyridoxal 5'-phosphate, PPi: Inorganic pyrophosphate, PEA: phosphoethanolamine, PL: Pyridoxial, HA: Hydroxyapatite, CPPD: Calcium pyrophosphate crystal deposition)

\section{Genetic mutations}

To date, around 317 mutations have been recorded in the TNSALP Gene Mutations Database (Mornet 2016). However, HPP with its subcategories carries a complex mode of inheritance with variable phenotypic expressions.

\subsection{Mode of inheritance}

Severe forms of HPP, primarily perinatal and infantile, are inherited in an autosomal recessive manner. Moderate forms (mHPP), primarily prenatal benign, childhood, adult, and odontohypophosphatasia, mostly result from heterozygosity of dominant severe alleles; severe and moderate alleles; or from two moderate alleles (Fauvert et al 2009). These moderate alleles were defined on the basis of clinical status and/or transfection studies. When tested in vitro, moderate alleles produce significant residual alkaline phosphatase activity; while severe alleles do not usually have enzymatic activity (Collmann et al 2009, Reibel et al 2103).

\subsection{Risk of transmission}

The risk of recurrence of severe forms is $25 \%$. In moderate forms, it may be $25 \%$ (recessive transmission), $50 \%$ (dominant transmission) or still different (less than 50\%) due to the variable expressivity of dominant forms. The mutations detected in dominant forms which are responsible for moderate HPP can be found in severe recessive HPP in association with other mutations (Herasse et al 2003).

\subsection{Variable phenotypic and genotypic expressions}

Interestingly, phenotypic expression of HPP is quite variable and does not clearly correlate with genotype, even within a given family of patients. In a few cases, however, patients with alleles classified as moderate exhibited a severe phenotype, probably because in vitro studies did not reflect the effect of these mutations; the effect of polymorphisms in ALPL; or other genes contributing to the regulation of bone metabolism (Sogabe et al 2008). Moreover, parents of patients affected with benign prenatal HPP express only very mild symptoms (mostly premature loss of teeth) or even, may be completely unaffected. This is also the case of 
families with mild HPP due to dominant missense mutations. So, dominance is sometimes difficult to demonstrate by using familial analysis, since expression of the disease may be highly variable, with parents of even severely affected children showing no or extremely mild symptoms of the disease (Pauli et al 1999). This may be attributable both to the progressive improvement of affected patients from infancy to adulthood, and to epigenetic factors involved in the disease variability (Lepe et al 1997).

\subsection{Improvement with age}

It is possible that in particular stages of development, ALP requirements are beyond the capacity of the heterozygous cell and results in HPP symptoms. Later on, ALP requirements may be decreased and filled by the heterozygous cell explaining the improvement among adult patients. Secondly, the maternal ALP plays a role via fetal-maternal exchanges, as suggested by the prenatal benign form that seems to be observed only when the mutation is inherited from the mother (Pauli et al 1999).

\subsection{Localization of mutations}

By using immunofluorescence and biochemical treatments, various mutations were characterized for their cell localization and degradation. These studies showed that most of the missense mutations found in severe HPP produced a mutant protein that failed to reach the cell membrane, remains accumulated in the cis-gogli and subsequently get degraded in the proteasome. Contrarily, the missense mutations responsible for mild HPP were found to be localized to the cell membrane. The severe missense mutations were shown to mostly affect residues localized in crucial domains of the protein; while mutations found in mild forms affect residues more randomly dispatched on the protein molecule (Brun-Heath et al 2007).

\section{Diagnosis}

A detailed history including age of onset, extent of symptoms, family history, and dental records; and thorough physical and dental examination were recorded. Blood, urine and radiographs were further ordered to confirm the diagnosis (Table 2) and rule out the differential diagnosis (Table 3). Careful attention must be paid to age-and gender-adjusted ALP reference ranges for accurate diagnosis of HPP. Furthermore, there is often a focus upon elevated ALP for the diagnosis of rickets/osteomalacia, rather than low ALP levels. Serum ALP activity is considerably higher in healthy infants, children, and adolescents compared with adults owing to an abundance of TNSALP in developing bone (Mornet 2016).

Various other parameters can be used in doubtful cases by measuring serum osteocalcin and urinary NTX levels using fasting, morning, second-void collections to monitor bone remodelling. Iliac crest biopsy specimens, obtained after tetracycline labeling, can be considered to demonstrate and quantify healing of osteomalacia in adult patients with HPP.
Table 2: List of Diagnostic Tests Used for Hypophosphatasia

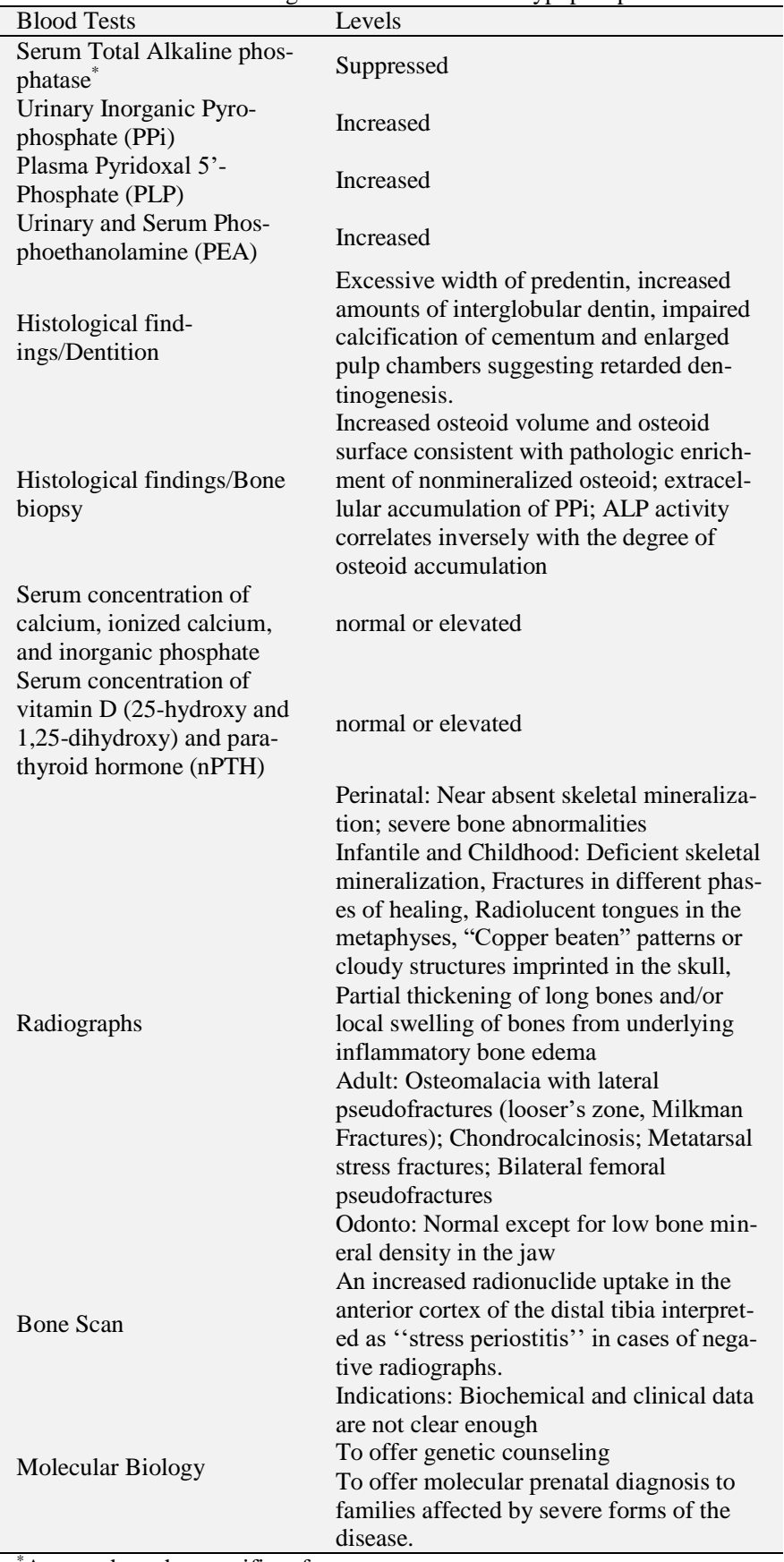

*Age- and gender-specific reference ranges

Table 3: List of Differential Diagnosis of Hypophosphatasia

\begin{tabular}{|c|c|c|c|}
\hline \multicolumn{4}{|c|}{ Conditions associated with suppressed levels of TNSALP } \\
\hline $\begin{array}{l}\text { Cardiac bypass } \\
\text { surgery }\end{array}$ & $\begin{array}{l}\text { Improperly } \\
\text { collected blood } \\
\text { (oxalate, } \\
\text { EDTA) }\end{array}$ & $\begin{array}{l}\text { Osteogenesis } \\
\text { imperfecta, type } \\
\text { II }\end{array}$ & $\begin{array}{l}\text { Pernicious or } \\
\text { profound } \\
\text { anemia }\end{array}$ \\
\hline Celiac disease & $\begin{array}{l}\text { Multiple mye- } \\
\text { loma }\end{array}$ & Hypothyroidism & $\begin{array}{l}\text { Vitamin D } \\
\text { intoxication }\end{array}$ \\
\hline $\begin{array}{l}\text { Clofibrate } \\
\text { therapy }\end{array}$ & $\begin{array}{l}\text { Radioactive } \\
\text { heavy metals } \\
\text { poisoning }\end{array}$ & Wilson's disease & $\begin{array}{l}\text { Vitamin C } \\
\text { deficiency }\end{array}$ \\
\hline $\begin{array}{l}\text { Cushing's } \\
\text { syndrome }\end{array}$ & $\begin{array}{l}\text { Milk-Alkali } \\
\text { syndrome }\end{array}$ & $\begin{array}{l}\text { Inappropriate } \\
\text { reference range }\end{array}$ & Starvation \\
\hline Chemotherapy & $\begin{array}{l}\mathrm{Zn}^{2+} \text { or } \mathrm{Mg}^{2+} \\
\text { deficiency }\end{array}$ & Early pregnancy & $\begin{array}{l}\text { Massive } \\
\text { transfusion }\end{array}$ \\
\hline
\end{tabular}




\section{Management}

\subsection{Wholesome approach}

There is no curative treatment of hypophosphatasia, but a multidisciplinary approach is required by endocrinologists, neurologists, orthopaedic surgeons, rheumatologists, pain management experts, dentist, nephrologists, geneticists, physical therapist and perhaps occupational therapists. Disease management is mainly directed toward the prevention or correction of disease-related complications. People with HPP benefit from a healthy lifestyle that includes safe exercise and avoiding smoking, excessive alcohol high caffeine consumption and steroid medications which will reduce bone density. Maintaining a healthy weight and avoiding activities with significant physical stress (e.g., martial arts, football, basketball) reduces stress on fragile bones. Family screening, genetic counseling, and prenatal diagnosis are other essential components of management plan.

\subsection{Role of vitamin, mineral supplements and bisphos- phonate}

Vitamin D and mineral supplements should be avoided, unless deficiencies are documented, because circulating levels of calcium, $\mathrm{Pi}$, and the vitamin $\mathrm{D}$ metabolites are typically not low. In infantile HPP, excessive vitamin D or mineral supplementation could provoke or exacerbate the hypercalciuria and hypercalcemia. Progressive skeletal demineralization may follow, but is probably due to the HPP per se if serum levels of calcium and Pi do not become low. On the other hand, restriction of vitamin D intake or sunshine exposure should be avoided, because superimposed vitamin Ddeficiency rickets has occurred in HPP. Although a significant number of HPP patients does indeed present with low levels of active vitamin D3. If a supplementation is considered, it must be administered under close monitoring, because Vitamin D can increase serum calcium levels and thus the risk of a nephrocalcinosis. Symptoms from CPPD or calcium phosphate crystal deposition in regard to pain and secondary metabolic inflammation resulting from the disease were shown to significantly improve with nonsteroidal anti-inflammatory medication (Girschick et al 1999). Bisphosphonates should be avoided because they are analogs of $\mathrm{PPi}$, lower bone turnover, and can inhibit ALPs by binding $\mathrm{Zn}^{2+}$ and $\mathrm{Mg}^{2+}$.

\subsection{Orthopaedic management}

Pseudofractures may progress to complete fractures even after conservative treatments (with casts, braces or protected weight bearing). Prophylactic intervention should be performed before any progression. Even prolonged immobility can further weaken bones and lead to muscle loss, weakness and more fractures. Intramedullary nail fixation ("rodding") is recommended for all pseudofractures even if asymptomatic (Coe et al 1986) due to their load sharing properties. Osteotomy and bone grafting may be necessary to facilitate nail insertion and prevent subsequent failure caused by delayed union, non-union or bone deformity (Leung et al 2008). Ankle-foot orthoses may be useful for recurrent metatarsal stress fractures.

\subsection{Neurological management}

Severely affected infants and young children with HPP should be followed carefully to detect neurological complications, such as increased intracranial pressure, from either "functional" or "true" craniosynostosis. Functional craniosynostosis can occur despite the radiographic illusion of widely open fontanels, and may require neurosurgical intervention. Frequent monitoring of head circumference and inspection of the optic discs should be undertaken.

\subsection{Dental management}

HPP can manifest as a severely compromised dentition impairing speech and nutrition, and therefore preservation of teeth in position or use of complete or partial dentures may be necessary. Expert dental care is highly recommended for those individuals with dental abnormalities.

\subsection{Placental ALP}

Intravenous injection of purified placental ALP was used to correct hypophosphatasemia in a severely affected infant under the view that plasma and urine PPi decrease after placental ALP correction of the hypophosphatasia among pregnant carriers of HPP. However, no clinical or radiographic improvement was found and these negative results suggested the greater tissue need for ALP, or it must be bound to plasma membranes for therapeutic efficacy (Whyte et al 1995).

\subsection{Teriparatide}

Whyte et al (2007) demonstrated the effect of teriparatide (a recombinant human parathyroid hormone; TPTD) given to the first HPP patient and found fracture repair accompanying correction of hypophosphatasemia and hyperphosphatemia; and bone marker responses indicating enhanced skeletal remodeling. Increased TNSALP synthesis in bone together with lowered extracellular concentrations of inorganic phosphate (a competitive inhibitor of ALPs) seemed to improve the skeletal mineralization. However, serum PLP level remained unchanged in keeping with TPTD effect directly on the skeleton; because deficient TNSALP activity in the liver continued to account for her elevated circulating PLP levels (Whyte 2002). Secondly, correction of hyperphosphatemia occurred during TPTD therapy results from its phosphaturic effect and/or from enhanced skeletal uptake of Pi during healing of presumed osteomalacia. Hence, lowering circulating (extracellular) Pi concentrations (vis-a-vis TPTD) enhanced endogenous TNSALP activity (Wenkert et al 2002).

However, TPTD responsiveness may differ considerably among patients with HPP. TPTD may prove most beneficial for dominantly inherited, mild forms of HPP, because wild-type TNSALP expression could be up-regulated. TPTD might be appropriate for patients with HPP with autosomal-recessive disease only if their TNSALP mutations do not abrogate enzymatic activity, prevent localization of the TNSALP dimer to matrix vesicles, or destroy its stability there. TPTD is currently contraindicated for pediatric patients because of concern for osteosarcoma developing within growth plates (Neer et al 2001).

\subsection{Enzyme replacement therapy}

ENB-0040 (asfotasealfa) is an investigational, recombinant, fusion protein administered subcutaneously 3-6 times per week comprises the TNSALP ectodomain, the constant region of the human IgG1 Fc domain, and a terminal deca-aspartate motif for bone targeting; restores the regulation of metabolic processes in the bones and teeth; and reduces complications of dysregulated bone mineral metabolism. Whyte et al (2016) reported 77\% survival in infants who suffered convulsions and were treated with ENB as compared with a $100 \%$ mortality rate in a set of historical control infants who were not treated. For those presenting early in life, such treatment has been shown to reduce mortality during the first year of life from $\sim 97 \%$ in perinatally presenting cases and close to $60 \%$ in cases presenting later in infancy to $\sim 10 \%$ overall. Continuous ENB resulted in improvements in bone mineralization and respiratory outcomes, such that of the $76 \%$ of the children who required ventilatory support at baseline and survived, $75 \%$ could be weaned from this support. It is likely that it causes local hydrolysis of PPi from the bone surface which diminishes circulating levels of PLP and PPi; and allows hydroxyapatite crystal growth, 
propagation, and skeletal mineralization to proceed. Antiasfotasealfa antibody levels, when present, were low, and there was no evidence of resistance to this treatment.

\subsection{Bone marrow transplantation}

Donor bone fragments and marrow may be used to provide precursor cells to form TNSALP and replete osteoblasts that can improve bone mineralization (Cahill et al 2007). Initial engraftment with hematopoietic stem cells (HSCs) is done to avoid the potential problem of mesenchymal stem cell (MSC) rejection. After successful HSC engraftment and the establishment of tolerance, sequential introductions of bone fragments and osteoblasts/MSCs intravenously in the setting of mixed chimerism depending on the precise nature and severity of the disease is done; however it may take considerable time to arrest and reverse the pathological skeletal process (Bianco et al 2001).

\subsection{Novel therapy via self-complementary adeno- associated virus (AAV8) vector}

Nakamura-Takahashi et al (2016) experimented TNSALPdeficient (Akp2-l-) mice with an intravenous injection of a recombinant adeno-associated virus (rAAV) expressing bonetargeted TNSALP with deca-aspartates at the C-terminus (TNSALP-D10) driven by the tissue-nonspecific CAG promoter. They constructed a self-complementary type 8 AAV (scAAV8) vector that expresses TNSALP-D10 via the muscle creatine kinase (MCK) promoter (scAAV8-MCK-TNSALP-D10) and examined the efficacy of muscle-directed gene therapy to develop a safer and more clinically applicable transduction strategy for HPP gene therapy. When scAAV8-MCK-TNSALP-D10 was injected into the bilateral quadriceps of neonatal mice, they found that the treated mice grew well and survived with a healthy appearance and normal locomotion for more than 3 months. Radiographs showed improved bone architecture with limited elongation of the long bone. Micro-CT analysis showed hypomineralization and abnormal architecture of the trabecular bone in the epiphysis. Hence, they concluded that rAAV-mediated, muscle-specific expression of TNSALP-D10 represents a safe and practical option to treat the severe form of HPP.

\section{Case history}

A 61-year-old male with past medical history of type 2 diabetes mellitus and hypertension presented for a routine check-up at an outpatient clinic. An incidental finding of decreased TNSALP on blood chemistry raises a suspicion of underlying pathology. He reported that he had two stress fractures of the left tibia at a very young age (10 and 18 years old); and had long leg casting for his fractures due to delayed healing along with long term pain management. The patient denied any other history of previous significant trauma or infection. Secondly, he had multiple reconstructive jaw surgeries due to poor development of his jaw since birth (Figure 4). Additionally he had a history of poor oral hygiene and early loss of teeth for which he underwent root canal around eight times and apical twice. He denies reporting of any delayed crawling/walking, chest deformity, premature deciduous teeth loss, and joint pains. On examination, all his vitals are within normal limits; he weighs around 121 pounds and 5 feet 9 inches tall giving a BMI of 17.9. His TNSALP has remained chronically low in the range of 20-30 U/L, Dual Energy X Ray absorptiometry shows osteoporosis with T-score -3.8 , and PLP is significantly elevated to $236 \mathrm{ng} / \mathrm{ml}(2.1-21.7 \mathrm{ng} / \mathrm{ml})$. His other laboratory including liver functions, thyroid functions, vitamin $\mathrm{D}$, serum calcium, serum phosphorus, serum protein electrophoresis, renal functions, lipid panel, vitamin $\mathrm{C}$, and complete blood count were normal. Hence, a final diagnosis of adult HPP was made. Unfortunately, we weren't able to get genetic results due to his non willingness to give consent and high cost of the genetic analysis test. He has been man- aged with strategies that improve the vital and functional prognosis; and maintain a high overall quality of care by ensuring his normal biochemical laboratory; encouraging healthy lifestyle; and regular dental appointments.

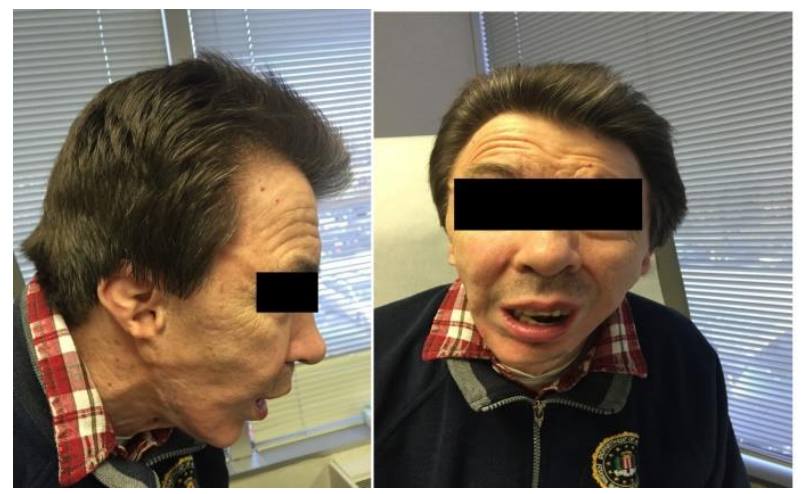

Fig. 4:Showing an Incision Line of Reconstructive Surgery Due to Poor Development of His Jaw since Birth

\section{Case discussion}

HPP is usually being diagnosed in infantile and childhood age. But in our case report, though a patient had multiple jaw reconstructive surgeries and early tooth loss in his childhood age but remained undiagnosed till his $60 \mathrm{~s}$. We suggests to screen for HPP by taking detailed history and ordering blood work in patients reported with low TNSALP. This can help in preventing various complication associated with HPP in elderly population including hypercalciuria, hypercalcemia and nephrocalcinosis from giving unusual vitamin D and calcium supplements; pseudo or complete fractures from minimal trauma and prolonged immobility; and poor dental hygiene with early tooth loss.

\section{Conclusion}

HPP is a rare inherited dento-osseous metabolic disease characterized by inactivating mutations in the gene encoding TNSALP which lead to a deficiency in TNSALP enzymatic activity. Low TNSALP activity results in increased levels of PPi, PLP, and PEA Accumulation of PPi impairs skeletal mineralization, causing rickets or osteomalacia despite normal or above-normal levels of calcium and inorganic phosphate. Although PLP levels are elevated, PLP is not dephosphorylated to PL, and therefore does not cross the blood-brain barrier or enter cells where it is normally rephosphorylated to PLP or converted to pyridoxamine-5, phosphate, to serve as cofactors in a variety of intracellular enzymatic reactions. We suggests to screen for HPP by taking detailed history and ordering blood work in patients reported with low TNSALP. This systematic review with novel approach and a case report should raise awareness among health care providers regarding low TNSALP and performing thorough etiological investigations which can ensure optimal clinical care and decision making for their patients by preventing complications like chondrocalcinosis, arthritis, early tooth loss, pseudo/complete fractures and pseudogout among the patients diagnosed even later in their life.

\section{References}

[1] Anderson HC, Hsu HH, Morris DC, Fedde KN, Whyte MP (1997) Matrix vesicles in osteomalacic hypophosphatasia bone contain apatite-like mineral crystals. American Journal of Pathology 151, 1555-1561.

[2] Anderson HC, Sipe JB, Hessle L, Dhanyamraju R, Atti E, Camacho NP, Millan JL (2004) Impaired calcification around matrix vesicles of growth plate and bone in alkaline phosphatase-deficient mice. American Journal of Pathology 164, 841847.http://dx.doi.org/10.1016/S0002-9440(10)63172-0. 
[3] Bianco P, Riminucci M, Gronthos S, Robey PG (2001) Bone marrow stromal stem cells: nature, biology, and potential applications. Stem Cells 19, 180-192http://dx.doi.org/10.1634/stemcells.19-3$\underline{180}$.

[4] Brun-Heath I, Lia-Baldini A, Maillard S, Taillandier A, Utsch B, Nunes ME, et al (2007) Delayed transport of tissue-nonspecific alkaline phosphatase with missense mutations causing hypophosphatasia. European Journal of Medical Genetics 50, 367378.http://dx.doi.org/10.1016/j.ejmg.2007.06.005.

[5] Buchet R, Millán JL, Magne D (2013) Multisystemic functions of alkaline phosphatases. Methods in Molecular Biology 1053, $27-$ 51.http://dx.doi.org/10.1007/978-1-62703-562-0_3.

[6] Cahill RA, Wenkert D, Perlman SA, Steele A, Coburn SP, McAlister WH, et al (2007) Infantile Hypophosphatasia: Transplantation Therapy Trial Using Bone Fragments and Cultured Osteoblasts. Journal of Clinical Endocrinology \& Metabolism 92, 2923 2930.http://dx.doi.org/10.1210/jc.2006-2131.

[7] Coe JD, Murphy WA, Whyte MP (1986) Management of femoral fractures and pseudofractures in adult hypophosphatasia. Journal of Bone \& Joint Surgery Am 68, 981-990.

[8] Collmann H, Mornet E, Gattenlohner S, Beck C, Girschick H (2009) Neurosurgical aspects of childhood hypophosphatasia. Childs Nervous System 25, 217-223.http://dx.doi.org/10.1007/s00381008-0708-3.

[9] Fauvert D, Brun-Heath I, Lia-Baldini AS, Bellazi L, Taillandier A, Serre JL, et al. (2009) Mild forms of hypophosphatasia mostly result from dominant negative effect of severe alleles or from compound heterozygosity for severe and moderate alleles. BMC Medical Genetics 10, 51, http://dx.doi.org/10.1186/1471-2350-10-51.

[10] Fraser D (1957) Hypophosphatasia. American Journal of Medicine 22, 730-746.http://dx.doi.org/10.1016/0002-9343(57)90124-9.

[11] Girschick HJ, Schneider P, Haubitz I, Hiort O, Collmann H, Beer M, Shin JS, Seyberth HW (2006) Effective NSAID treatment indicates that hyperprostaglandinism is affecting the clinical severity of childhood hypophosphatasia. Orphanet Journal of Rare Disease 1, 24.http://dx.doi.org/10.1186/1750-1172-1-24

[12] Herasse M, Spentchian M, Taillandier A, Keppler-Noreuil K, Fliorito AN, Bergoffen J, et al (2003) Molecular study of three cases of odontohypophosphatasia resulting from heterozygosity for mutations in the tissue non-specific alkaline phosphatase gene. Journal of Medical Genetics 40, 605 9.http://dx.doi.org/10.1136/jmg.40.8.605.

[13] Ho AM, Johnson MD, Kingsley DM (2000) Role of the mouse ank gene in control of tissue calcification and arthritis. Science 289, 265-270http://dx.doi.org/10.1126/science.289.5477.265.

[14] Lepe X, Rothwell BR, Banich S, Page RC (1997) Absence of adult dental anomalies in familial hypophosphatasia. Journal of Periodontal Research 32, 375-380.http://dx.doi.org/10.1111/j.16000765.1997.tb00547.x.

[15] Leung EC, Mhanni AA, Reed M, Whyte MP, Landy H, Greenberg CR (2013) Outcome of perinatal hypophosphatasia in Manitoba Mennonites: a retrospective cohort analysis. JIMD Reports 11, 73 78.http://dx.doi.org/10.1007/8904 2013224

[16] Leung HW, Wong CW, Shen WY (2008) Intramedullary nailing for adult hypophosphatasia: a case report. Journal of Orthopaedic Surgery $16,385-388$.

[17] Mornet E. The tissue nonspecific alkaline phosphatase gene mutations database. Accessed on June 5, 2016 from http://www.sesep.uvsq.fr/03_hypo_mutations.php

[18] Mornet E, Yvard A, Taillandier A, Fauvert D, Simon-Bouy B (2011) A molecular- based estimation of the prevalence of hypophosphatasia in the European population. Annals ofHuman Genetics 75, 439445.http://dx.doi.org/10.1111/j.1469-1809.2011.00642.x.

[19] Mumm S, Jones J, Finnegan P, Whyte MP (2001) Hypophosphatasia: Molecular Diagnosis of Rathbun's Original Case. Journal of bone and mineral research 16, 1724 1727.http://dx.doi.org/10.1359/jbmr.2001.16.9.1724.

[20] Nakamura-Takahashi A, Miyake K, Watanabe A, Hirai Y, Iijima O, Miyake N et al. (2016) Treatment of hypophosphatasia by muscledirected expression of bone-targeted alkaline phosphatase via selfcomplementary AAV8 vector. Molecular Therapy - Methods \& Clinical Development 15059.http://dx.doi.org/10.1038/mtm.2015.59.

[21] Neer RM, Arnaud CD, Zanchetta JR, Prince R, Gaich GA, Reginster JY et al (2001) Effect of parathyroid hormone (1-34) on fractures and bone mineral density in postmenopausal women with osteoporosis. New England Journal of Medicine 344, 14341441.http://dx.doi.org/10.1056/NEJM200105103441904

[22] Pauli RM, Modaff P, Sipes SL, Whyte MP (1999) Mild hypophosphatasia mimicking severe osteogenesisimperfecta in utero: bent but not broken. American Journal of Medical Genetics 86, 434 438.http://dx.doi.org/10.1002/(SICI) 1096 8628(19991029)86:5<434:AID-AJMG8>3.0.CO $2-\mathrm{C}$

[23] Reibel A, Maniere MC, Clauss F, Droz D, Alembik Y, Mornet E, Bloch-Zupan A (2009) Orodental phenotype and genotype findings in all subtypes of hypophosphatasia. Orphanet Journal of Rare Disease 4, 6, http://dx.doi.org/10.1186/1750-1172-4-6.

[24] Sogabe N, Oda K, Nakamura H, Orimo H, Watanabe H, Hosoi T, Goseki-Sone M (2008) Molecular effects of the tissue-nonspecific alkaline phosphatase gene polymorphism $(787 \mathrm{~T}>\mathrm{C})$ associated with bone mineral density. Biomedical Research 29, 213 219.http://dx.doi.org/10.2220/biomedres.29.213

[25] Wenkert D, Podgornik MN, Coburn SP, Ryan LM, Mumm S, Whyte MP (2002) Dietary phosphate restriction therapy for hypophosphatasia: preliminary observations. Journal of Bone and Mineral Research 17, S384.

[26] Whyte MP (2002) Hypophosphatasia: nature's window on alkaline phosphatase function in man. In: Bilezikian JP, Raisz LG, Rodan GA, eds. Principles of bone biology. 2nd ed. San Diego, CA: Academic Press; 1229-1248.http://dx.doi.org/10.1016/B978012098652-1/50172-4.

[27] Whyte MP, Landt M, Ryan LM et al (1995) alkaline phosphatase: placental and tissue-nonspecific isoenzymes hydrolyze phosphoethanolamine, inorganic pyrophosphate, and pyridoxal 5'- phosphate. Substrate accumulation in carriers of hypophosphatasia corrects during pregnancy. The Journal of Clinical Investigation, 95, 14401445.http://dx.doi.org/10.1172/JCI117814.

[28] Whyte MP, Leung E, Wilcox W, et al (2001) Hypophosphatasia. In: Scriver CR, Beaudet AL, Sly WS, Valle D, eds. The Metabolic and Molecular Bases of Inherited Disease. Vol 4. 8th ed. New York, NY: McGraw-Hill, 5313-5329

[29] Whyte MP, Rockman-Greenberg C, Ozono K, et al (2016) Asfotasealfa treatment improves survival for perinatal and infantile hypophosphatasia. Journal of Clinical Endocrinology \& Metabolism 101, 334-342.http://dx.doi.org/10.1210/jc.2015-3462.

[30] Whyte MP, Steven Mumm, Chad Deal (2007) Adult Hypophosphatasia Treated with Teriparatide. The Journal of Clinical Endo-

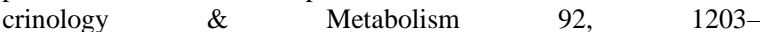
1208.http://dx.doi.org/10.1210/jc.2006-1902. 